\title{
Stanovení hodnot minimálních zůstatkových průtoků v podmínkách ČR
}

\section{PAVEL BALVÍN, ADAM VIZINA}

Klíčová slova: minimální zůstatkový průtok - regionální rozdělení - sezonní rozdělení MZP - nařízení vlády - ekologické průtoky

\section{SOUHRN}

Nový metodický př́stup stanovení minimálních zůstatkových průtoků (dále jen MZP) slouží jako podklad pro nařizení vlády ČR a samozřejmě vyvolává širokou diskusi nad jeho dopadem, a to jak z hlediska ochrany prírody, tak rovněž, a to především, z hlediska jeho dopadu na nakládání s vodami a hospodaření na nádržích. Už v počátcích řešení a hledání nového přístupu bylo jasné, že nebude možné najít ideální rovnováhu a uspokojit všechny zúčastněné. Problematika MZP totiž vyvolává přirozený rozkol mezi nakládáním s vodami a ochranou př́rody a jen u minima prípadů Ize nalézt ideální kompromis. Dosud platný metodický pokyn z roku 1998 je úměrný své době, ale nevyhovuje požadavkům na tzv. ekologické průtoky, rovněž výpočet směrných hodnot ve skokovém režimu nelze považovat za spravedlivý. Nový přístup je založen na regionálním rozdělení respektující hranice povodí a odlišné hydrologicko-geologické charakteristiky. Do výpočtu MZP zavádí více hydrologických charakteristik a vytváří podmínky pro sezonní rozdělení MZP během roku.

Článek předkládá souhrn poslední verze způsobu stanovení hodnot minimálních zůstatkových průtoků, dokumentuje zvolený prístup a porovnává změny hodnot MZP s původním metodickým pokynem z roku 1998.

\section{ÚVOD}

Novela zákona č. 254/2001 Sb. z roku 2010 byla zásadním impulsem pro přehodnocení dosavadního prístupu k problematice minimálních zůstatkových průtoků. Novela $\S 36$ stanovila, že způsob a kritéria stanovení minimálního zůstatkového průtoku podle druhého odstavce stanoví vláda nařizením. MŽP ČR následně pověřilo Vúv TGM, v. v. i., přehodnocením dosavadního prístupu používaném v metodickém pokynu MŽP ČR z roku 1998. VúV TGM, v. v. i., byl zároveň pověren, aby do způsobu stanovení MZP implementoval nové postupy a kritéria, která by více zohledňovala hydrologickou variabilitu jednotlivých regionů ČR, sezonně rozdělila velikost MZP během roku a posoudila velikost MZP z hlediska tzv. ekologických průtoků.

Minimálním zůstatkovým průtokem se podle § 36 vodního zákona rozumí průtok povrchových vod, který ještě umožňuje obecné nakládání s vodami a ekologické funkce vodního toku. Vodní zákon v platném znění ukládá vodoprávním úřadům stanovit hodnotu minimálního zůstatkového průtoku s přihlédnutím k podmínkám vodního toku, charakteru nakládání s vodami a k opatřením k dosažení cílů ochrany vod príijatých v plánu povodí. Tyto požadavky dané zákonem bylo třeba zohlednit v návrhu nového metodického přístupu, který bude sloužit jako podklad pro zpracování nařizení vlády. Nově navržený koncept vychází z doposud platného metodického pokynu Odboru ochrany vod Ministerstva životního prostředí k zásadám stanovení hodnot minimálních zůstatkových průtoků ve vodních tocích z roku 1998 [1]. S cílem lepšiho zohlednění požadavků vodních ekosystémů, ekosystémů vázaných na vodní prostředí, environmentálních standardů používaných $v$ jiných zemí EU a požadavků MŽP ČR, byl oproti původnímu pokynu uplatněn regionální přístup ke stanovení hodnoty MZP. Hodnota MZP je proměnná v roce a při jejím stanovení se přihlíži i k cíli ochrany vod pro dotčený vodní útvar.

Velikost minimálního zůstatkového průtoku má značný vliv na ekologický i na chemický stav vodního útvaru dotčeného nakládáním s vodami, nebot’ zajištuje prežití vodních a na vodu vázaných ekosystémů v období sucha a zajištuje dostatečné ředění vypouštěných vod. $V$ tomto kontextu je možné se v literatuře setkat s termínem ekologický (environmentální) průtok. Velikost ekologického průtoku je zpravidla stanovována na základě znalosti specifik dané lokality, ke kterým patří např. struktura ekosystému (převažující, chráněné druhy organismů a rostlin), hydromorfologie dotčeného úseku toku, výskyt habitatů atd. Pro stanovení velikosti ekologického průtoku existuje raada expertních metod, které však v každém př́padě vyžadují odborné posouzení konkrétní lokality a jsou často časově i finančně náročné. Není tedy možné je doporučit pro rutinní stanovení hodnoty MZP vodoprávním úřadem pro všechna povolovaná nakládání s vodami. Při odvození nové metodiky stanovení MZP byla snaha približit se co nejvíce konceptu ekologického průtoku [2], ale zároveň vypracovat metodu uplatnitelnou $v$ praxi.

\section{DATA}

Pro návrh nového způsobu stanovení MZP byly k dispozici statistické charakteristiky průtoků pro 276 vodoměrných stanic z celé ČR za období 1981-2010, které byly pořizeny od Českého hydrometeorologického ústavu (ČHMÚ). Sledované charakteristiky zahrnovaly velikost dlouhodobého ročního průměrného průtoku, p-procentní a M-denní průtoky, koeficient variace a asymetrie řady denních průtoků, hodnoty průměrného průtoku $v$ jednotlivých měsících $v$ roce a hodnoty pravděpodobnostního pole průměrných měsíčních průtoků. Střední hodnota velikosti plochy povodí vybraných vodoměrných stanic činí 222 km².

ČHMÚ stanovuje M-denní průtoky na základě pozorovaných hodnot, které odpovídají přirozenému nebo více či méně ovlivněnému hydrologickému režimu. I když je pro výpočet MZP doporučeno vycházet právě z odovlivněných hodnot hydrologických charakteristik, bylo nutno přistoupit k pragmatickému řešení a ve výsledném nařízení vlády budou použity pouze hydrologické charakteristiky odvozené z pozorovaných, tedy mnohdy ovlivněných, průtoků. Tento pragmatický prístup byl $v$ počátcích považován za jediný možný, ale postupem času byl silně kritizován, a to především v souvislosti se stanovením MZP na vodních dílech sloužících k akumulaci vod. 


\section{NÁVRH REGIONÁLNÍHO ROZDĚLENÍ ČR}

Zohlednění prírodních podmínek toku při návrhu regionalizace ČR bylo založeno především na uvážení klíčových procesů podílejících se na tvorbě celkového odtoku z povodí. Bylo třeba vymezit oblasti, kde si celkový odtok po většinu roku zachovává vyrovnaný charakter, a tedy nedochází k výraznému poklesu vodnosti toku v létě a na začátku podzimu. Jedná se především o oblasti, kde je celkový odtok po většinu roku dotován ze zásob podzemních vod. Na druhou stranu bylo třeba vymezit oblasti, které mohou být potenciálně zranitelné vůči suchu, kde je celkový odtok během roku výrazně nevyrovnaný. Pro návrh regionalizace byl vybrán parametr K99, který udává poměr mezi průměrným denním průtokem s pravděpodobností překročení $99 \%$ během referenčního období a hodnotou průměrného dlouhodobého průtoku $Q_{a}$ za stejné období. Čím vyšší je hodnota parametru, tím vyrovnanější chod průtoků během roku můžeme předpokládat.

Hodnoty parametru K99 $v$ testovaných vodoměrných stanicích byly vykresleny do mapy hydrogeologických rajonů. Na základě souvislosti hodnot parametru K99, hydrogeologických poměrů a nadmořské výšky bylo navrženo rozdělit území ČR do čtyř kategorií. Samostatnou třídu tvoří kategorie kř́idových sedimentů, které představují drenážní báze a kde základní odtok, tj. odtok ze zásob podzemních vod, tvoří podstatnou část celkového odtoku. Patří sem některé př́itoky Labe, horní Metuje, Loučná, pramenné oblasti Svitavy a Třebůvky a tok Říčka. Hodnota parametru K99 je v těchto oblastech zpravidla větší než 0,18. Druhou třídu tvoří horská území, která jsou rovněž relativně vodná. Vyrovnaný charakter odtoku je zde dán především vysokými srážkami. Hodnota parametru K99 je $\checkmark$ těchto územích zpravidla větší než 0,15. Do této třídy byly zařazeny predevším Krkonoše a Jizerské hory, Šumava, Jeseníky, vrcholky Krušných hor a dále i část povodí Tiché Orlice, která má obdobně vyrovnaný charakter. Třetí kategorii představují oblasti tvořené převážně krystalinickými strukturami, které se nacházejí v podhưří pohraničních pohoří a v oblasti Českomoravské vrchoviny. Jedná se o území s velmi podobným průběhem čáry překročení jako u třídy 2. Vzhledem k nižší nadmořské výšce, než která je dosahována v oblastech kategorie 2, zde dochází k dřivějšímu nástupu období jarního tání. Také srážky jsou zde nižší než u kategorie 2. Hodnota parametru K99 se v těchto oblastech zpravidla pohybuje od 0,1 do 0,15. Do čtvrté kategorie byly klasifikovány oblasti, které se vyznačuji výrazně nevyrovnaným režimem průtoků během roku, kde hodnota parametru K99 je menší než 0,1. Mapa rozdělení ČR do jednotlivých kategorí je na obr. 1 .

\section{NÁVRH ZPŮSOBU STANOVENÍ MZP PODLE NOVÝCH KRITÉRIÍ}

Navržený způsob stanovení MZP má dostatečně respektovat potřeby vodních ekosystémů a ekosystémů na vodu vázaných. V první řadě byl proveden rozbor existujících studií zaměřených na stanovení hodnoty MZP s využitím expertní metody „Instream Flow Incremental Methodology“ (dále jen IFIM) [3]

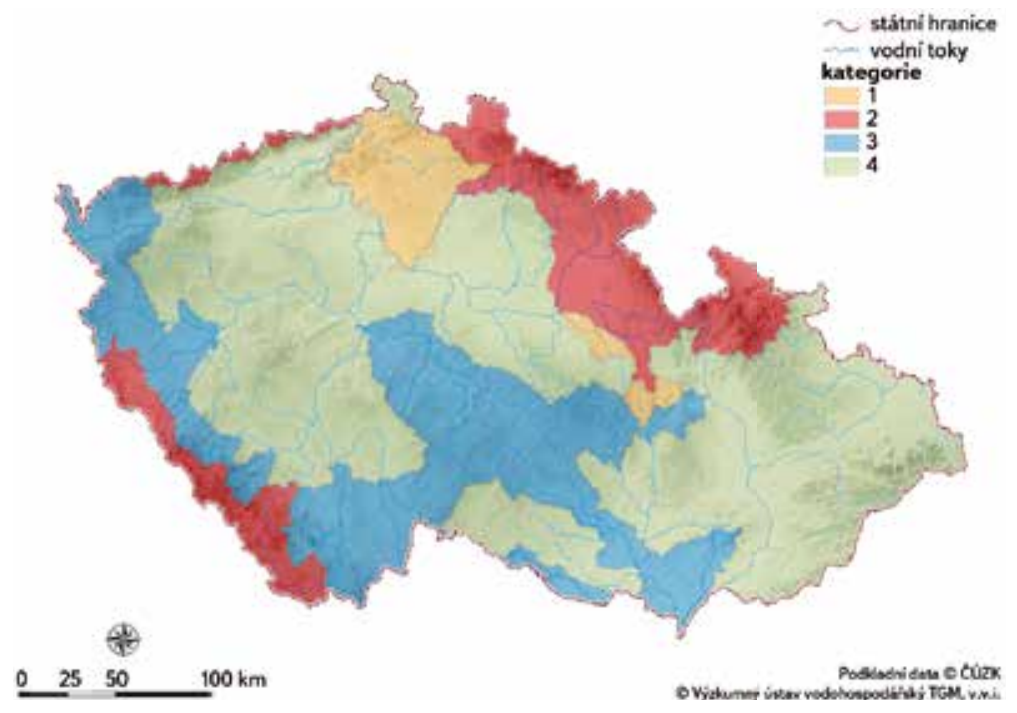

Obr. 1. Rozdělení ČR do čtyř kategorií podle K99

Fig. 1. Division of the Czech Republic into 4 categories according to K99

v podmínkách ČR. Jedná se o metodu, která využívá pro stanovení hodnoty MZP výsledky rekognoskace zájmového úseku toku z hlediska jeho hydraulických parametrů, charakteru habitatu a vyskytujících se živočišných a rostlinných druhů. Metoda zahrnuje simulaci vážené využitelné plochy habitatu při různě velkých průtocích. Výsledky simulačního modelování pomocí modelu Phabsim (modelový nástroj metodiky IFIM) jsou dále uplatněny při diskusi nad volbou kompromisní úrovně MZP, která umožní zachování stávajících ekosystémů a zároveň umožní rozumnou míru nakládání s vodami [4]. Odvození hodnoty MZP pomocí metody IFIM trvá zpravidla 1,5 až 2 roky a vyžaduje opakovaný sběr biologických a hydraulicko-hydrologických dat z úseku toku, který bude dotčený navrhovaným nakládáním. Rešerše zahrnovala 15 lokalit $\vee$ ČR a vedla k závěru, že výsledná ideální hodnota MZP se ve většině případů pohybovala na úrovni průtoku s pravděpodobností překročení 330 dní v roce.

Studie provedené na základě metody IFIM byly většinou zpracovány pro lokality $\checkmark$ oblastech kategorií 2 a 3, tedy horských a podhorských oblastech. Pro tyto kategorie platí, že hodnota $Q_{330 d}$ činí približně 26-31\% Q (viz tabulku 1). Z tabulky je rovněž patrné, že pro kategorii 1 odpovídá průtoku o velikosti $30 \% \mathrm{Q}_{a^{\prime}}$ průtok s dobou prekekročení 364 dní v roce, zatímco pro stanice v zařazené do kategorie 4 by se jednalo o průtok s dobou překročení príbližně 300 až 270 dní v roce. Pro návrh metody stanovení MZP byl dále uvažován orientační požadavek, aby MZP činilo přibližně 20-30 \% Q. Tento požadavek je v souladu se závěry dokumentu „Environmental Flows as a tool to achieve the WFD Objectives - discussion paper" [5]. V prvních pracovních verzích tohoto dokumentu bylo doporučeno pro dosažení dobrého ekologického stavu zajistit ekologický průtok v rozsahu 25-50\% $Q_{a^{\prime}}$ navržená

Qmd $/ \mathbf{Q}_{\mathrm{a}}[-]$

\begin{tabular}{llllllll}
\hline Kategorie & $\mathbf{Q}_{\mathbf{2 1 0 d}}$ & $\mathbf{Q}_{\mathbf{2 4 0 d}}$ & $\mathbf{Q}_{\mathbf{2 7 0 d}}$ & $\mathbf{Q}_{\mathbf{3 0 0 d}}$ & $\mathbf{Q}_{\mathbf{3 3 0 d}}$ & $\mathbf{Q}_{\mathbf{3 5 5 d}}$ & $\mathbf{Q}_{\mathbf{3 6 4 d}}$ \\
\hline 1 & 0,72 & 0,65 & 0,59 & 0,53 & 0,46 & 0,38 & 0,29 \\
\hline 2 & 0,57 & 0,5 & 0,43 & 0,37 & 0,31 & 0,17 & 0,18 \\
\hline 4 & 0,54 & 0,46 & 0,39 & 0,33 & 0,26 & 0,11 & 0,08
\end{tabular}




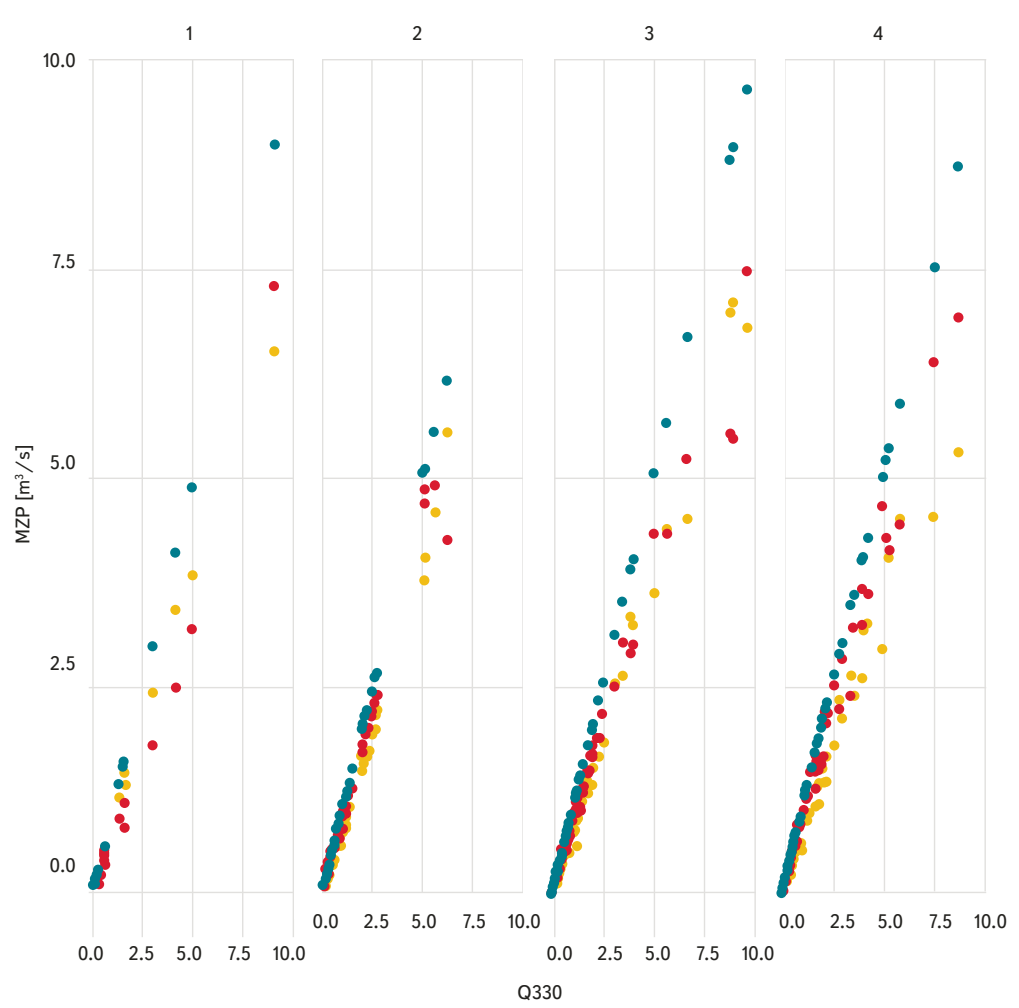

Obr. 2. Porovnání hodnot MZP podle platného metodického pokynu MŽP (oranžová barva) a navrhovaných hodnot podle nové metodiky pro hlavní (červeně) a jarní (modře) sezonu pro jednotlivé kategorie

Fig. 2. Comparison of the values of the MZP according to the valid methodological instruction of the Ministry of the Environment (orange color) and the proposed values according to the new methodology for the main (red) and spring (blue) season for individual categories

úroveň 20-30 \% tedy představuje dolní hranici z daného rozpětí. Nicméně, zde je nutno podotknout, že v současné době již nejsou tyto hodnoty v dokumentu uváděny. Vzhledem k výše uvedeným faktům bylo rozhodnuto, že výpočet MZP bude odvozován od hodnoty průtoku s pravděpodobností prekekročení 330 dní v roce.

Původní metodický pokyn pro stanovení MZP z roku 1998 pracuje se skutečností, že s velikostí vodního toku se průtokový režim stává vyrovnanější, a pro stanovení MZP u vodnějších toků je doporučeno uplatnit hodnoty průtoku s vyšší pravděpodobností překročení. Podobný prístup je rovněž uplatněn např. ve švýcarském vodním zákoně [6], kde velikost minimálního zůstatkového průtoku (residual water flow) roste v závislosti na hodnotě průtoku s pravděpodobností překročení 347 dní v roce s mocninou menší než 1 . Aby byl popsaný princip zachován i v nově navrhované metodice stanovení MZP, bylo nejprve provedeno vyhodnocení závislosti podílu průtoku s dobou překročení 330 dní $\checkmark$ roce a dlouhodobého průměrného průtoku $Q_{a}$ na velikosti průtoku $Q_{330 d}$.

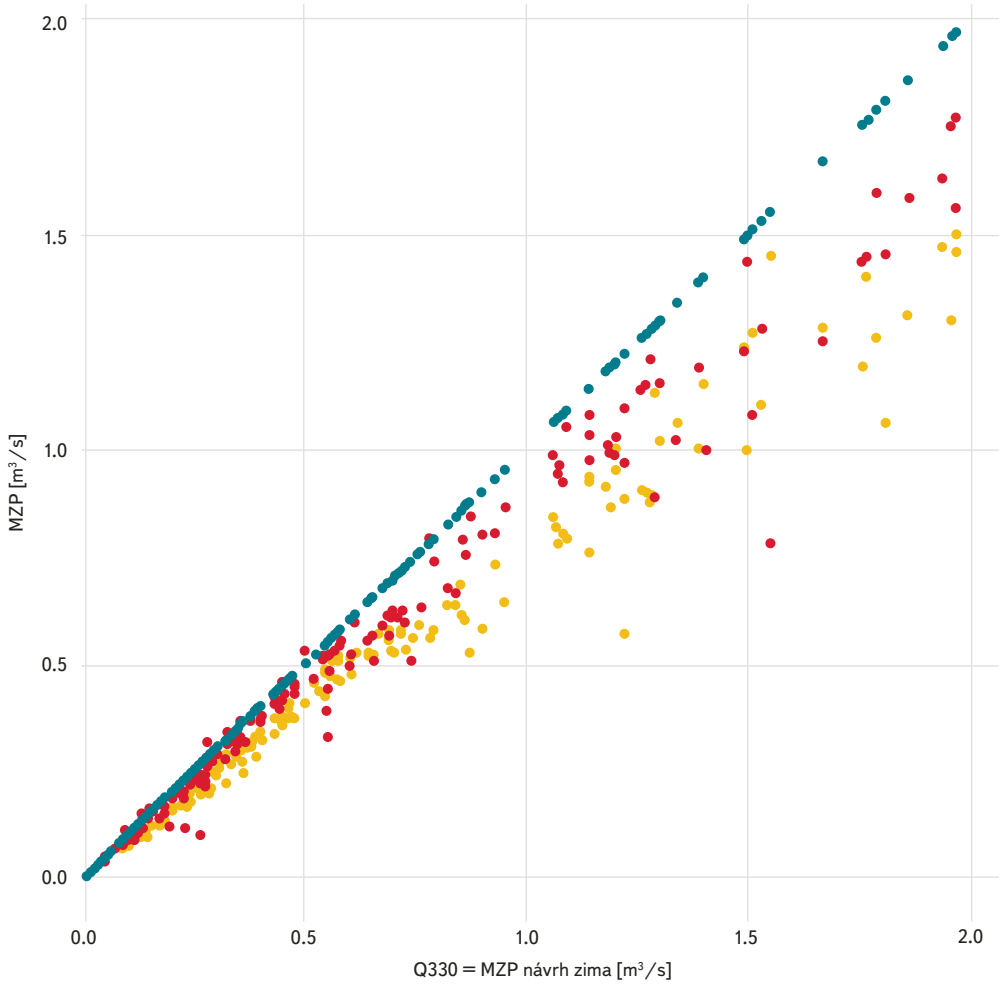

Obr. 3. Porovnání hodnot MZP podle platného metodického pokynu MŽP (oranžová barva) a navrhovaných hodnot podle nové metodiky pro hlavní (červeně) a jarní (modre) sezonu pro jednotlivé kategorie

Fig. 3. Comparison of the values of the MZP according to the valid methodological instruction of the Ministry of the Environment (orange color) and the proposed values according to the new methodology for the main (red) and spring (blue) season for individual categories

Pro odvození vztahu vhodného pro stanovení MZP pro jednotlivé kategorie byla vykreslena funkce podílu návrhové hodnoty $M Z P / Q_{330 d}$ na velikosti $Q_{330 d}$ pro jednotlivé kategorie zvlášt. Nicméně bylo rozhodnuto, že míra redukce velikosti MZP v závislosti na velikosti řídicího průtoku $Q_{330 d}$ bude pro celé území ČR stejná a rozdílný bude parametr násobku v rovnici. Výsledné rovnice pro stanovení MZP pro jednotlivé kategorie byly odvozeny opět z požadavku dosažení poměru $M Z P / Q_{a}$ približně na úrovni $25 \%$. Výsledné rovnice jsou uvedeny v tabulce 2.

Součástí zadání ze strany Ministerstva životního prostředí bylo rovněž rozdělení hodnoty MZP do minimálně dvou období, která by tak více popisovala rozdělení průtoku během roku. Tím by bylo zajištěno, že oproti původnímu metodickému pokynu by MZP nebyl konstantní během celého roku, ale $v$ jarním období by docházelo k navýšení MZP. Výsledným rozdělením MZP během roku bylo stanovení tzv. hlavní sezony v období květen až leden a jarní sezony v období únor-duben.

Tabulka 2. Návrh výpočetního postupu pro stanovení MZP v jednotlivých kategoriích pro dvě sezony v roce

Table 2. Draft calculation procedure for determining the MZP in individual categories for two seasons of the year

\section{Kategorie}

Hlavní sezona

\begin{tabular}{lllll}
\hline 1 & květen-leden & $\left(1-\mathrm{Q}_{355 \mathrm{~d}} / \mathrm{Q}_{\mathrm{a}} \mathrm{Q}_{330 \mathrm{~d}} 1,1\right.$ & únor-duben & $\mathrm{Q}_{330 \mathrm{~d}}$ \\
\hline 2 & květen-leden & $\left(1-\mathrm{Q}_{355 \mathrm{~d}} / \mathrm{Q}_{\mathrm{a}}\right) \mathrm{Q}_{330 \mathrm{~d}} 1,2$ & únor-duben & $\mathrm{Q}_{330 d}$ \\
\hline 3 & květen-leden & $\left(1-\mathrm{Q}_{355 \mathrm{~d}} / \mathrm{Q}_{\mathrm{a}} \mathrm{Q}_{330 \mathrm{~d}} 1,05\right.$ & únor-duben & $\mathrm{Q}_{330 d}$ \\
\hline
\end{tabular}




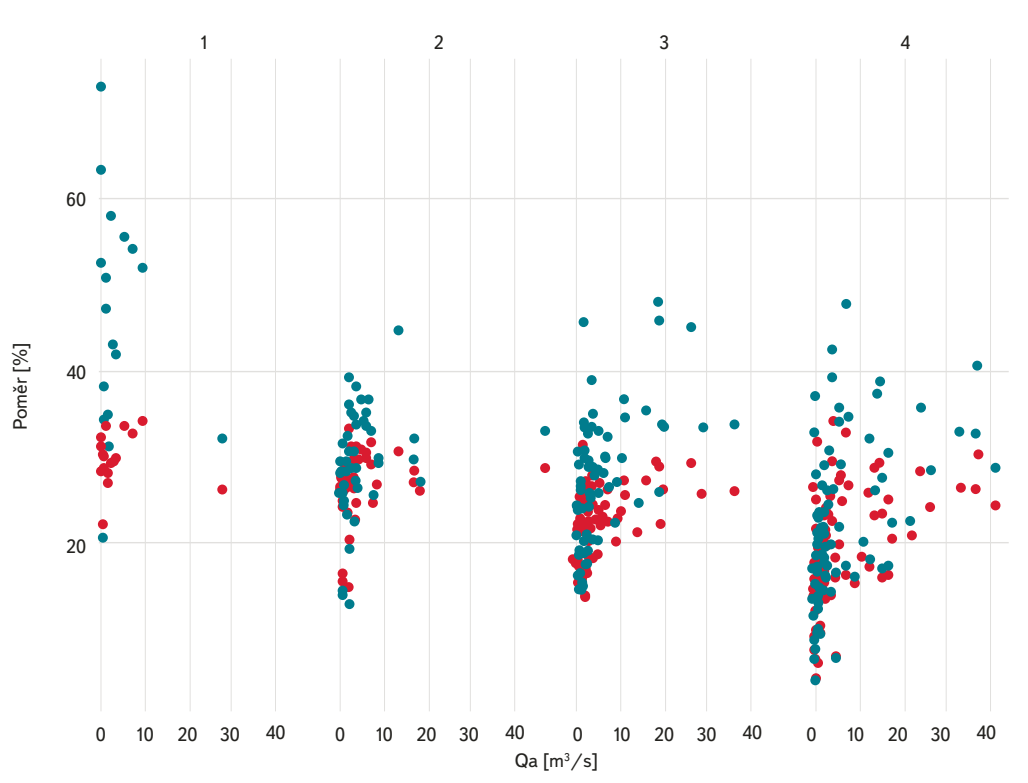

Obr. 4. Poměr hodnoty MZP k průtoku Qa - červeně hlavní sezona, modře jarní sezona Fig. 4. The ratio of the value of the MZP to the Qa flow - the red main season, the blue spring season

\section{VYHODNOCENÍ NAVRŽENÉHO PŘÍSTUPU STANOVENÍ MZP}

V následující kapitole jsou zobrazeny výsledky a je provedeno porovnání návrhových hodnot minimálního zůstatkového průtoku s hodnotami stávajícími. Analýza byla provedena na 276 povodích v České republice. Většina profilů má však průměrný průtok do $2 \mathrm{~m}^{3} . \mathrm{s}^{-1}$. Po návrhu byla na daných povodích provedena citlivostní analýza, která měla za cíl posoudit, zda v jednotlivých měsících jsou navrhované hodnoty MZP reálné a zda je možné v méně vodných měsících těchto hodnot dosáhnout s určitou pravděpodobností. Pro posouzení byly také napočítány nedostatkové objemy s konstantní a variabilní limitní hodnotou. Tyto nedostatkové objemy byly porovnány s hodnotami nedostatkových objemů, kde vstupem byla konstantní limitní hodnota platného MZP. Podmínkou pro hodnocení bylo, aby jednotlivá událost měla délku minimálně 5 dní a mezi jednotlivými událostmi byly alespoň dva dny [7].

Na obr. 2 jsou zobrazeny navrhované hodnoty MZP pro letní (červeně), zimní (modře) sezonu a současné (oranžově) hodnoty MZP rozdělené do jednotlivých kategorií. Na ose x jsou zobrazeny hodnoty $Q_{330 d}$ a na ose y jsou vyneseny hodnoty MZP. V tomto prípadě jsou zobrazena všechna hodnocená povodí. Na obr. 3 jsou potom pouze povodí, jejichž hodnota $Q_{330 d}$ je menší nebo rovna $2 \mathrm{~m}^{3} . \mathrm{s}^{-1}, \mathrm{z}$ důvodu lepší prezentace výsledků. Na tomto grafu je provedena sumarizace pro všechny kategorie. Lze pozorovat, že všechny navrhované hodnoty jsou pod hodnotou $Q_{330 d}$ a $v$ prípadě malých průtoků jsou rozdíly minimální a dá se uvažovat, zda jsou tyto rozdíly vůbec měřitelné. Tento problém se však vyskytuje u všech toků, kde se vyskytují nízké průtoky (desítky l/s).

Na obr. 4 jsou zobrazeny poměry navrhovaných hodnot MZP pro hlavní (červeně) a jarní (modře) sezonu k hodnotám $Q_{a}$. Z grafu je možné pozorovat, že se tyto poměry pohybují kolem $22 \%$ pro hlavní sezonu ( $29,4 \%$ pro kategorii 1, 26,8 \% pro kategorii 2, 22,7 \% pro kategorii 3 a 18,6 \% pro kategorii 4) a $26 \%$ pro sezonu jarní (44,3\% pro kategorii 1, 29,6\% pro kategorii 2, 27,4\% pro kategorii 3 a $21 \%$ pro kategorii 4). Na obr. 5 jsou poté tyto poměry pro hlavní sezonu zobrazeny na ploše České republiky. Vyšší hodnoty u jarní sezony nejsou na škodu, jelikož v tomto období je vody dostatek a neměl by být problém tyto hodnoty splňovat.

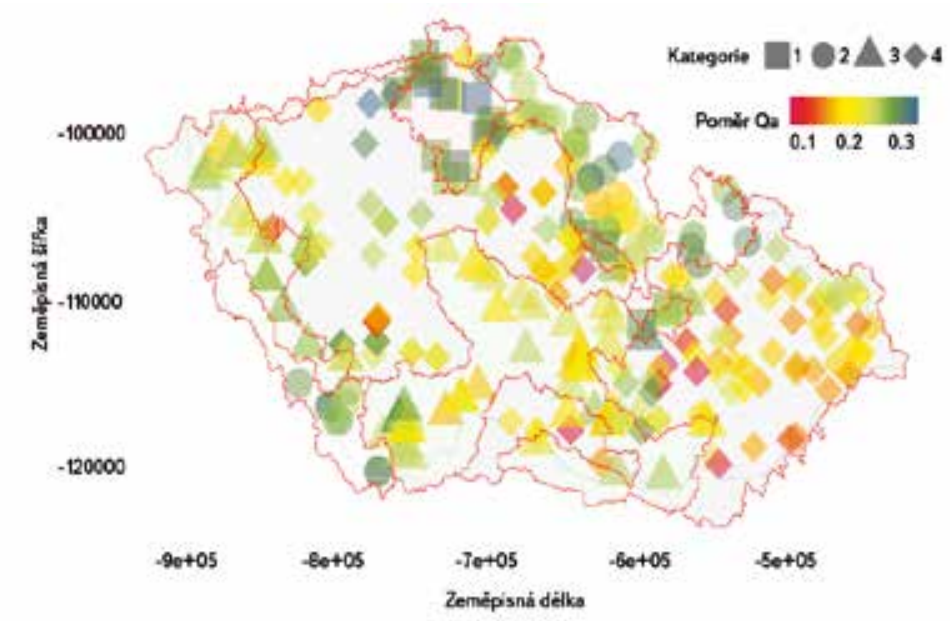

Obr. 5. Plošné rozmístění poměru hodnoty MZP k průtoku Qa (hlavní sezona) Fig. 5. Area distribution of the ratio of the MZP to the Qa flow (main season)

Na obr. 6 jsou změny navrhovaného MZP pro obě sezony k hodnotě stávající reprezentovány grafem typu boxplot, u kterého obdélník udává kvantily 25\% a 75\%, čára uprostřed boxu medián a jednotlivé čáry vycházející z boxu $6 \%$ a 95\% kvantily. Hodnoty jsou rozděleny do jednotlivých kategorií (na ose x). Na ose y je potom procentuální změna od současné hodnoty pro všechna povodí rešená v dané kategorii. Na obr. 7 jsou potom tyto změny pro hlavní sezonu rozloženy do plochy České republiky. Lze pozorovat, že změny pro hlavní sezonu (červeně) se průměrně pohybují od $25 \%$ pro kategorii 1 do cca $20 \%$ u kategorie 2 . U sezony vedlejší jsou tyto změny cca o 20 \% vyšší.

\section{VÝSLEDKY A DISKUSE}

Nový prístup stanovení minimálních zůstatkových průtoků, který slouží jako podklad pro nařízení vlády ČR, přináší zcela jistě oproti pưvodnímu, ale stále ještě platnému metodickému pokynu z roku 1998 zásadní změny. Zvolený přístup ve většině případů vede ke zvýšení požadavků na MZP oproti směrným hodnotám, které odpovídají požadavkům původního metodického pokynu z roku 1998. Zprísnění podmínek se týká především toků v kategorii 4 s rozkolísaným průtokovým režimem, která podle navržené regionalizace na území ČR plošně převažuje.

Metodický pokyn z roku 1998 stanovuje hodnotu MZP především na základě tabulky směrných hodnot, kdy je základním kritériem hodnota $\mathrm{Q}_{355 \text { d }}$. Už samotný pojem směrné hodnoty umožňuje na jedné straně jistou flexibilitu při stanovení MZP, ale na straně druhé je jasné, že se jedná o hrubý odhad, to metodický pokyn sám přiznává. Stanovení MZP je rovněž skokové, což není spravedlivé a z hydrologického hlediska př́liš logické. Nicméně, je to věc zvoleného prístupu odpovídající své době. Další argument mluvící v neprospěch stávajícího prístupu je založen na tvrzení, že zmiňovaná tabulka nebyla původně vůbec odvozena pro stanovení hodnot MZP, ale pro potřeby ředění odpadních vod pod ČOV. Ze strany orgánů ochrany prírody jsou všeobecně hodnoty MZP vyplývající z metodického pokynu chápány jako nízké a př́stup je príliš flexibilní.

Nově zvolený přístup je komplexnější, ale to s sebou samozřejmě přináší širší pohled na věc a s tím i logické komplikace. Na základě zadání a požadavku ze strany MŽP měl nový prístup zohlednit hydrologickou variabilitu v podobě regionálního rozdělení ČR respektující hranice povodí. V př́ipadě nového přístupu se jedná o hranice povodí 4. rádu. Autoři nového přístupu si jsou zcela vědomi, že jakýkoli pokus o regionální rozdělení plochy ČR z hlediska hydrologické variability pro potřeby stanovení MZP musí být zatížen jistým zjednodušením 


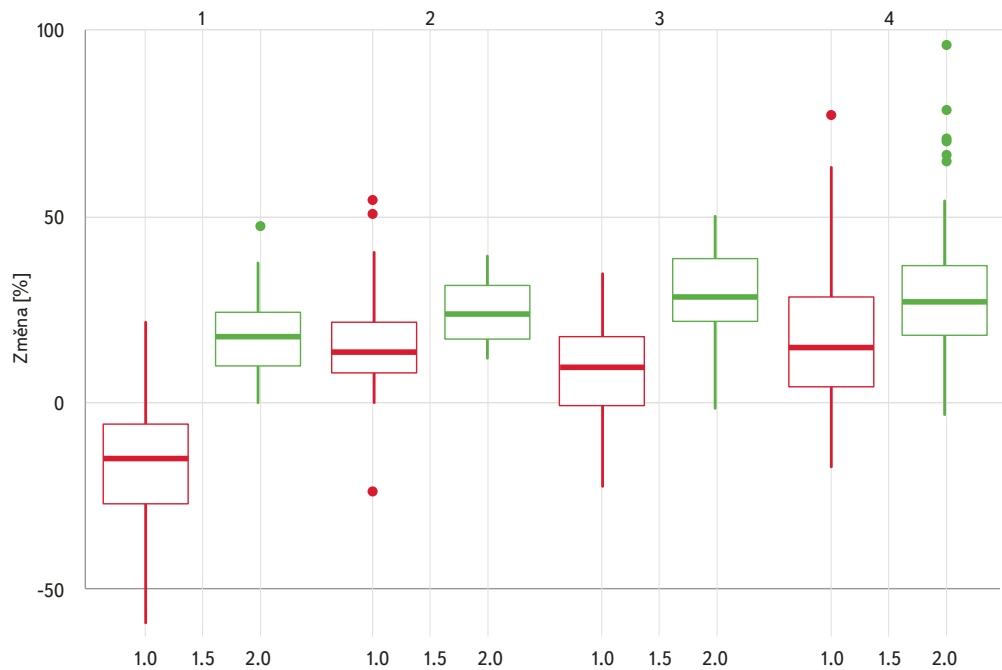

Obr. 6. Změna hodnoty MZP (návrh/současná hodnota) - červeně hlavní sezona, zeleně jarní sezona

Fig. 6. Change in the value of the MZP (proposal/current value) - red main season, green spring season

a nelze postihnout všechny charakteristické typy povodí. Nicméně, rozdělení podle koeficientu $\mathrm{K} 99\left(\mathrm{Q}_{99 \%} / \mathrm{Q}_{a}\right)$ je z našeho pohledu považováno za dostatečně reprezentativní, aby popsal vyrovnanost odtokového režimu.

Vzorce, které jsou pak následně použity pro výpočet hodnoty MZP, zavádí do výpočtu více hydrologických charakteristik $\left(\mathrm{Q}_{a^{\prime}} \mathrm{Q}_{355 \mathrm{~d}^{\prime}} \mathrm{Q}_{330 \mathrm{~d}}\right)$ než stávající metodický pokyn. Navrhovaný postup tak přispívá k objektivnějšímu stanovení MZP.

Hodnoty MZP jsou odvozeny tak, aby byl poměr MZP/Q cca $25 \%$. Tento požadavek vyplynul z požadavku na tzv. ekologický průtok, který byl uváděn $\checkmark$ původních textech dokumentů EU [7]. Zde je nutno poznamenat, že tento požadavek (doporučení) již není v dokumentech EU uváděn, ale v požadavcích na nový metodický přístup byl ponechán.

Z hlediska sezonního rozdělení MZP Ize konstatovat, že rozdělení MZP během roku je zcela logické a v sousedních (západních) státech zcela běžné. Je nutno poznamenat, že již původní metodický pokyn doporučoval rozdělit zůstatkový průtok sezonně během roku a kladl značný důraz na vazbu s biologií, predevším na ryby a zoobentos.

Sezonní dělení MZP však s sebou nese určité provozní komplikace, které jsou spojeny především s vlastním měřením obou sezonních hodnot. Obě hodnoty se liší maximálně 10-20\%, a to je z hlediska měření a souvisejících nejistot málo. Může se pak stát, že vyšší hodnota v jarní sezoně bude těžko kontrolovatelná oproti hodnotě v hlavní sezoně, jelikož si budou např. na vodočetné lati velice blízké

Samostatnou kapitolu tvoři nádrže, kde se hodnota MZP nestanovuje na základě metodického pokynu, ale podle účelu vodního díla a tedy na základě vodohospodářského rešení nádrže. Z hlediska stanovení hodnot MZP je nemožné odvodit univerzální vzorec pro výpočet MZP, který by byl aplikovatelný na multifunkční vodní díla, nebo tato vodní díla kategorizovat podle určitých parametrů a následně pro ně odvodit příslušný algoritmus výpočtu MZP. Jaké řešení a prístup zvolit? Přestože nové nařízení nebude mít zpětnou platnost, je zde $v$ případě nádrží riziko, že $v$ rámci přehodnocení manipulačního řádu může dojít i k přehodnocení MZP. To s sebou nese riziko, že nově nastavený MZP způsobí problémy z hlediska zabezpečenosti jednotlivých funkcí nádrže a nádrž nebude schopna plnit svoji funkci např. zásobování pitnou vodou. Aby k těmto situacím nedocházelo, mělo by nařízení vlády umožnit výjimku, která by umožnila stanovit MZP odpovídající účelům vodního díla. Z hlediska nádrží je nutné se domnívat, že tuto výjimku bude nutno uplatnit na všechny významnější nádrže v ČR.

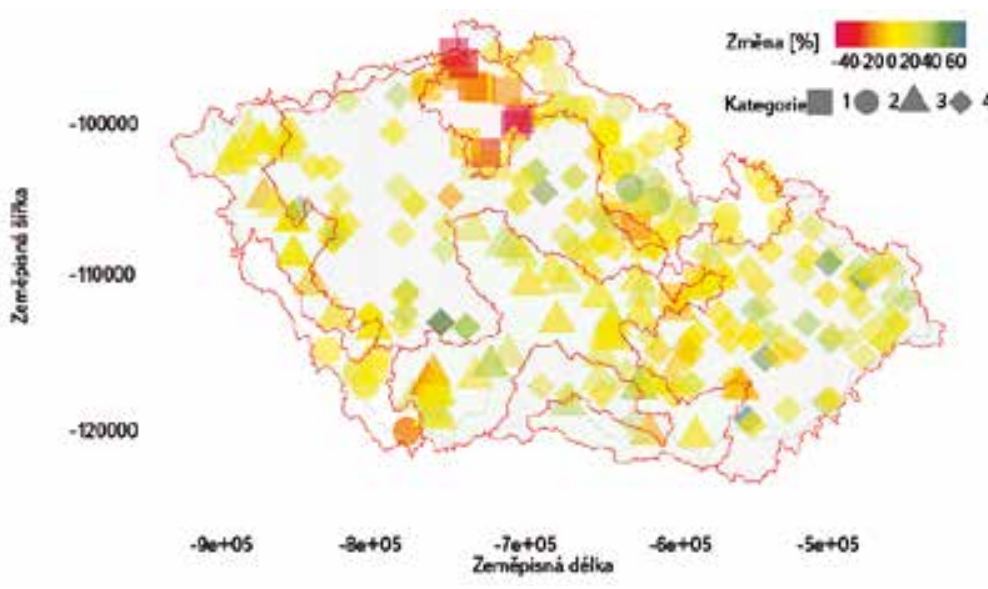

Obr. 7. Plošná distribuce změny hodnoty MZP (návrh/současná hodnota) - (hlavní sezona)

Fig. 7. Area distribution of change in the value of the MZP (proposal/current value) (main season)

\section{ZÁVĚR}

Závěrem Ize konstatovat, že problematiku nového způsobu stanovení MZP čeká jistě zajímavá diskuse. Diskuse bude o to zajímavější, že v současnosti probíhá meziresortní připomínkové řízení. Z důvodu zpracování nařizení vlády v paragrafovém znění jsou totiž možnosti nastavení specifických kritérií, např. formou doporučení, velice omezené.

\section{Poděkování}

Autoři by rádi poděkovali všem, kteři spolupracovali nejen na prípravě nového prístupu, ale i těm, kteři se svou konstruktivní kritikou zasloužili o vývoj prístupu až do současné podoby.

\section{Literatura}

[1] MŽP. Metodický pokyn odboru ochrany vod Ministerstva životního prostředí ke stanovení hodnot minimálních zůstatkových průtoků ve vodních tocích č. j. ZP16/98, 1998. Dostupné z: https://www. mzp.cz/web/edice.nsf/BB978B5BAEDF46C0C1256FC8003F1EB8/\$file/metod.html

[2] Ecological flows in the implementation of the Water Frame Directive, Guidence document No. 31. [3] BOVEE, K.D., LAMB, B.L., BARTHOLOW, J.M., STALNAKER, C.B., TAYLOR, J., and HENRIKSEN, J. Stream habitat analysis using the instream flow incremental methodology: U.S. Geological Survey Information and Technology Report 1998-0004. 1998, 130 p. Dostupné z: http://www.fort.usgs.gov/ Products/Publications/3910/preface.html

[4] BALVÍN, P. a MRKVIČKOVÁ, M. Stanovení minimálních zůstatkových průtoků. Vodohospodářské technicko-ekonomické informace (VTEI), 2011, roč. 53, č. 4, s. 1-3, přiloha Vodního hospodářství č. 2011

[5] EK. Environmental Flows as a Tool to Achieve the WFD Objectives - discussion paper, 2012. Dostupné z: https://circabc.europa.eu/sd/d/0898cf3d-657a-4018-b53d-b34ac3460997/55171-EflowsDiscpap-Ed2-20120613.pdf

[6] FASC. Federal Law on the Protection of Water 814.20. The Federal Assembly of the Swis Confederation, 1991

[7] VIZINA, A., VLNAS, R., KAŠPÁREK, L., HANEL, M. a HRABÁNKOVÁ, A. Hydrologické sucho v České republice. SOVAK, 2015, 7-8/2015, s. 38-43 
